RHODORA, Vol. 116, No. 967, pp. 000-000, 2014

(c) Copyright 2014 by the New England Botanical Club

DOI: 10.3119/13-26; first published on-line Month xx, 2014.

\title{
ADDITIONAL LICHEN RECORDS AND MINERALOGICAL DATA FROM METAL-CONTAMINATED SITES IN MAINE
}

\author{
Ian D. Medeiros
}

College of the Atlantic, 105 Eden Street, Bar Harbor, ME 04609

\author{
Alan M. Fryday \\ Herbarium, Department of Plant Biology, Michigan State University \\ 612 Wilson Road, East Lansing, MI 48824 \\ ${ }^{1}$ Nishanta Rajakaruna \\ College of the Atlantic, 105 Eden Street, Bar Harbor, ME 04609; \\ Unit for Environmental Sciences and Management, North-West University, \\ Private Bag X6001, Potchefstroom, 2520, South Africa \\ ${ }^{1}$ Author for Correspondence; e-mail: nrajakaruna@coa.edu
}

ABSTRACT. Geochemistry and mineralogy of rocks play important roles in the occurrence of individual lichen species and assembly of lichen communities. Whereas lichens of metal-enriched settings have been a focus of study for many decades, only a few such lichen inventories exist for North America. We reexamined the lichen biota of Pine Hill, a serpentine outcrop on Little Deer Isle, Maine and Callahan Mine, a copper- and zinc-enriched Superfund site in Brooksville, Maine by conducting additional field surveys and reexamining unidentified taxa from previous collections. To better characterize the substrates upon which the lichens were found, we conducted elemental analyses via $\mathrm{x}$-ray fluorescence and inductively coupled plasma-mass spectrometry on rock samples collected at Pine Hill and recorded $\mathrm{pH}$, electrical conductivity, and elemental concentrations via inductively coupled plasma mass spectrometry on soil samples from Callahan Mine. The re-investigation of lichens of the two metal-enriched sites resulted in the addition of 20 taxa to Pine Hill and 10 taxa to Callahan Mine. These include Dermatocarpon leptophyllodes, Placynthiella hyporhoda, Pyrenocarpon thelostomum, and Vezdaea acicularis, all recorded for the first time from New England. In addition, we report the first documented records since the late 19th to early 20th century for New England of Porocyphus coccodes, Sarcosagium campestre, and Steinia geophana, and the first such record for Maine for Coccocarpia palmicola. Stereocaulon condensatum and $S$. subcoralloides, both considered as rare in New England, were also collected from Callahan Mine.

Key Words: edaphic ecology, lichen ecology, Maine lichens, metal quarries, metal-tolerance, serpentine, superfund sites

Areas of soil and exposed bedrock rich in heavy metals are geologically and ecologically distinct from surrounding areas and 
may support distinct floras resulting from their disjunction (O'Dell and Rajakaruna 2011). These areas can be anthropogenic in origin, such as mines where waste accumulation on the surface has dramatically changed the landscape, or naturally occurring, such as outcrops of ultramafic rock. Decades of research have suggested that these "edaphic islands" may harbor a high proportion of endemic plants that have evolved to tolerate edaphic stresses (Kay et al. 2011; Rajakaruna and Boyd 2008). Often-quoted examples include the flora of the island of New Caledonia, which has abundant ultramafic rock outcrops and far more endemic species than many larger islands (Anacker 2011), and California, which supports a high number of species endemic to specific geologies, including ultramafic rocks such as serpentinite (Kay et al. 2011; Safford et al. 2005).

Ultramafic rocks contain at least $70 \%$ ferromagnesian silicate minerals (Kruckeberg 2002); soils weathered from such rocks tend to have ratios of calcium $(\mathrm{Ca})$ to magnesium $(\mathrm{Mg})<1$, low levels of essential nutrients such as nitrogen $(\mathrm{N})$, potassium $(\mathrm{K})$, and phosphorous $(\mathrm{P})$, and high levels of heavy metals such as chromium (Cr), nickel (Ni), and cobalt (Co) (Brady et al. 2005). The impact of geologically unique environments on plant diversity is especially apparent on serpentinite outcrops (hereafter referred to as serpentine), where high levels of heavy metals and low essential nutrients such as $\mathrm{Ca}$ limit long-term habitation to those species that possess mechanisms for edaphic tolerance (Kruckeberg 1986). Serpentine environments exert strong selective pressure on plants, and adaptations to these unique edaphic conditions drive speciation and high rates of endemism (Kay et al. 2011; Kruckeberg 1986; O'Dell and Rajakaruna 2011). Because of the distinctiveness and global rarity of many of the plants found on serpentine and their potential use for the study of plant ecology and evolution (Harrison and Rajakaruna 2011), the vascular flora of serpentine outcrops have been documented extensively in western North America, New Caledonia, Cuba, and Europe (Roberts and Proctor 1992).

Like serpentine outcrops, metal mines are also edaphically stressful environments that typically have shallow and rocky soils with low levels of plant nutrients and large concentrations of heavy metals (O'Dell and Rajakaruna 2011). Plants growing on metalenriched mine tailings, like those on serpentine outcrops, are often physiologically distinct and reproductively isolated from their relatives growing on nearby uncontaminated soil (Antonovics 
2006; O'Dell and Rajakaruna 2011), providing opportunities for the study of ecological speciation (Kay et al. 2011).

Compared to vascular plants, lichens on serpentine outcrops have received less attention (Favero-Longo et al. 2004; Rajakaruna et al. 2012) and, as with vascular plants, very little of the research has been carried out in eastern North America (Harris et al. 2007; Rajakaruna et al. 2009; Reed 1986; Sirois et al. 1988). This is somewhat surprising considering that New England has received extensive lichenological study, including investigations of sites with unique geologies (see Miller et al. 2005). Brodo (1973) remarked that since there is a close relationship between lichen and substrate, edaphically extreme substrates may have unique effects on lichens. For example, cryptogams have shown high specificity on calcareous substrates (Bates 1978). Conversely, a comprehensive review of the literature on lichens of serpentine outcrops by Favero-Longo et al. (2004) showed no evidence of serpentine endemism in lichens. Lichens are apparently less affected by ultramafic substrata than vascular plants, possibly because of differences in cell wall structure that render the low level of $\mathrm{Ca}$ in ultramafic rocks less detrimental to lichens than to vascular plants (O'Dell and Rajakaruna 2011). Another possible explanation is that the acids produced by many lichens can form complexes with a range of elements, thus neutralizing their toxicity (Wilson 1995). However, it is possible that the physical structure of a rock is as important to the lichen biota as its mineralogy, and that climate, elevation, history of land use, and other biotic and abiotic factors may have as much, or more, influence on the lichen biota as any chemical or physical properties of the rock itself; see Rajakaruna et al. (2012) and references therein for a full discussion of lichen-metal relations.

Despite their apparent lack of substrate specificity, lichens are able to accumulate heavy metals from metal-rich substrates (Bačkor and Loppi 2009; Lambinon et al. 1964; Maquinay et al. 1961) and unique lichen ecotypes and mixtures of calcicolous and silicicolous species are often found on serpentine outcrops (Favero-Longo et al. 2004; Rajakaruna et al. 2012). The potential for unique lichen assemblages on serpentine outcrops suggests that anthropogenic, metal-enriched sites may also provide similar challenges for lichens. Purvis (1993) states that the debris left by copper mining creates habitat for a variety of lichen species, including those that are rare, a factor that should be taken into consideration when old mine sites undergo reclamation. 
To date, only two published studies have documented the lichen biota of metal-enriched sites and serpentine outcrops in coastal New England. Both studies deal with sites with histories of mining or quarrying in Hancock County, Maine, U.S.A. Harris et al. (2007) catalogued the lichens of Pine Hill, an abandoned peridotite quarry on Little Deer Isle. A species list for the site was presented and compared with lists of lichen species recorded in nearby Acadia National Park (Sullivan 1996) and serpentine outcrops worldwide (Favero-Longo et al. 2004). Comparison between these lists showed that Pine Hill hosted two species previously unreported from New England, three species previously unreported from Maine, and 20 species previously unreported from serpentine outcrops worldwide. The latter category included Lobaria, a genus not previously reported from serpentine elsewhere. Rajakaruna et al. (2011) examined Callahan Mine, a copper- and zinc-enriched Superfund site in Brooksville. This study provided a species list for the site, including information on the general ecology of each species and notes on which species were previously known to tolerate or accumulate specific heavy metals. This study did not generate any new records for Maine or New England, but the authors did note the presence of two taxa described as regionally rare or declining, and two taxa reported as copper tolerant.

The primary objective of the current study was to conduct additional field surveys at Pine Hill and Callahan Mine to find species that might have been overlooked during the previous efforts. Additionally, unidentified lichens collected by Harris et al. (2007) and Rajakaruna et al. (2011) were identified during the current study. We also investigated the elemental chemistry of the serpentine rocks at Pine Hill and the ionic content and other chemical features of the soils at Callahan Mine to better characterize substrate tolerances for the lichens we collected. We compared the lichen biota of Pine Hill and Callahan Mine to a published species list for serpentine from Québec (Sirois et al. 1988) and to that of nearby Acadia National Park, Maine (Sullivan 1996) to determine whether any species we found were previously undocumented from serpentine substrates and other habitats in northeastern North America.

MATERIALS AND METHODS

Site descriptions. Pine Hill is a former peridotite quarry occupying about 40 acres on Little Deer Isle, Hancock County, 
Maine, USA $\left(44^{\circ} 17^{\prime} 07.3^{\prime \prime} \mathrm{N}, 68^{\circ} 42^{\prime} 06.7^{\prime \prime} \mathrm{W}\right.$; WGS 84$)$. The outcrop is serpentinized peridotite formed during the Jurassic period (Hooke 2003). Quarry activities from approximately 1930-1960 have reduced the outcrop to a half dome and exposed extensive vertical faces of unweathered rock with a southern exposure. The quarry floor is largely serpentinized gravel overlying bedrock, with a number of large boulders near the base of the outcrop. Soils on the site range from coarse gravel on the quarry floor, to humus-rich organic debris along the three sides of the outcrop, and sandy loam at the top of the outcrop. A number of ephemeral freshwater seeps exist at the site, creating moist environments in an otherwise dry landscape. For additional information on the site see Briscoe et al. (2009), Harris et al. (2007), and Pope et al. (2010).

Callahan Mine is a former intertidal open-pit mine in Brooksville, Hancock County, Maine ( $44^{\circ} 20^{\prime} \mathrm{N}, 68^{\circ} 48^{\prime} \mathrm{W}$; WGS 84$)$. It has been mined intermittently since 1880 , the most intensive mining taking place from 1968-1972. Callahan Mine was listed as a Superfund site in 2002 (Environmental Protection Agency 2013) due to elevated levels of heavy metals, including copper $(\mathrm{Cu})$, zinc $(\mathrm{Zn})$, lead $(\mathrm{Pb})$, and cadmium $(\mathrm{Cd})$, and organic contaminants such as PCBs (Rajakaruna et al. 2011). The site is currently under remediation. For a detailed site description see Rajakaruna et al. (2011) and Mansfield et al. (2014).

Rock elemental analysis. Elemental analysis via x-ray fluorescence (XRF) was conducted on one composite rock sample each from Pine Hill (serpentine) and nearby Settlement Quarry (granite) as a comparison. An automated sequential XRF spectrometer (Advant'XP+, Thermo ARL, Switzerland) was used, and was run at $60 \mathrm{keV}$ and $60 \mathrm{~mA}$ with a rhodium target. Elemental concentrations were determined for major (Al-Ti) and trace (As- $\mathrm{Zr}$ ) elements. For detailed analytical methodology see Rajakaruna et al. (2012). Inductively coupled plasma-mass spectrometry (ICP-MS) was used to analyze additional trace elements that were not determined by XRF analysis. The procedure consists of a low-dilution fusion with dilithium tetraborate (Spectromelt ${ }^{\circledR}$ A-10, EM Science, Gibbstown, $\mathrm{NJ}$ ) followed by an open-vial mixed acid digestion. Reagents were $\mathrm{HNO}_{3}$ 69-70\% (Fisher ACS plus grade), HF 48-52\% (Baker ACS reagent grade), $\mathrm{HClO}_{4} 67-71 \%$ (Fisher Trace Metal Grade), and $\mathrm{H}_{2} \mathrm{O}_{2}$ (Baker ACS Reagent). The HF was further purified before use by sub-boiling distillation in a teflon still. All water used was 
$>18 \mathrm{M}$ deionized water from a Nanopure analytical grade water system (Barnstead/Thermolyne, Dubuque, IA). Powdered rock samples were mixed with an equal amount of dilithium tetraborate flux (typically $2 \mathrm{~g}$ ), placed in a carbon crucible and fused at $1000^{\circ} \mathrm{C}$ in a muffle furnace for $30 \mathrm{~min}$. After cooling, the resultant fusion bead was briefly ground in a carbon-steel ring mill and a $250 \mathrm{mg}$ portion was weighed into a $30 \mathrm{ml}$, screw-top Teflon PFA vial for dissolution. The acid dissolution consisted of a first evaporation with $\mathrm{HNO}_{3}(2 \mathrm{ml})$, $\mathrm{HF}(6 \mathrm{ml})$, and $\mathrm{HClO}_{4}(2 \mathrm{ml})$ at $110^{\circ} \mathrm{C}$. After evaporating to dryness, the sample was wetted and the sides of the vial were rinsed with a small amount of water before a second evaporation with $\mathrm{HClO}_{4}(2 \mathrm{ml})$ at $160^{\circ} \mathrm{C}$. After the second evaporation, samples were brought into solution by adding approximately $10 \mathrm{ml}$ of water, $3 \mathrm{ml} \mathrm{HNO}_{3}, 5$ drops $\mathrm{H}_{2} \mathrm{O}_{2}$, and 2 drops HF, and warmed on a hot plate until a clear solution was obtained. The sample was then transferred to a clean $60 \mathrm{ml}$ HDPE bottle and diluted up to a final weight of $60 \mathrm{~g}$ with deionized water. Solutions were analyzed on an Agilent Model 4500 ICP-MS and were diluted an additional $10 \times$ at the time of analysis using Agilent's Integrated Sample Introduction System (ISIS; Agilent Technologies, Santa Clara, CA). All analyses were performed at the Hooper GeoAnalytical Laboratory, Washington State University, WA, USA.

Soil chemical analysis. The lichens at Callahan Mine were collected from within or close to the plots established by Mansfield et al. (2014). Therefore, we used the same soil chemical data reported in their Table 4 (for the tailings pond, waste rock piles, and habitats 'in between') to better characterize the range of tolerance to various soil chemical features for the lichens we collected. Methods of soil analyses are reported in Mansfield et al. (2014).

Lichen identification. Lichens for this study were collected by $\mathrm{R}$. C. Harris (New York Botanical Garden, NY, USA) in 2009 and by one of us (A.M.F.) in 2013. Several unidentified Cladonia and Lepraria specimens, collected in 2004 by T. B. Harris as part of the original Pine Hill lichen survey (Harris et al. 2007) and deposited at HCOA, were also identified for this project by one of us (I.D.M.). Lichens were identified by A.M.F. and I.D.M. using a variety of published keys, including Brodo et al. (2001), Gowan and Brodo (1988), and Hinds and Hinds (2007). Two collections that we were unable to identify to species (Aspicilia and Lichinaceae) were 
sent to experts in these groups. Thin-layer chromatography was performed and secondary metabolites identified according to procedures and data in Orange et al. (2001). Nomenclature follows Esslinger (2012). Voucher specimens for this study and Harris et al. (2007) have been deposited at HCOA, MSC, NBM, and NY.

Lichen distribution data for North America are mostly scattered within the literature and difficult to obtain. The recent innovation of the Consortium of North American Lichen Herbaria (CNALH), which aims to digitize the label data from all lichen collections in North American herbaria, was initiated to correct this deficit and we have based our assumptions of species' distributions on records contained in this database. This is an unsatisfactory solution, but the best that is currently available. Additionally, the distribution of New England macrolichens was based on Hinds and Hinds (2007).

\section{RESULTS}

Recent collections and re-examination of previously collected lichen material have resulted in the addition of 20 taxa to the species list for Pine Hill, and 10 taxa to that of Callahan Mine (Appendix). There are now 82 lichen taxa from 40 genera known from Pine Hill and 84 lichen taxa from 41 genera known from Callahan Mine. Fifty-nine percent (48/82) of the Pine Hill taxa and 64\% (54/84) of the Callahan Mine taxa are shared with the lichen biota of Acadia National Park as documented by Sullivan (1996), the most recent comprehensive lichenological survey of the Park. Fifty-two percent of Pine Hill taxa (43/82) are shared with Sirois et al. (1988), the only published study of lichens of serpentine rocks in northeastern North America besides the current study and Harris et al. (2007).

The new collections include Dermatocarpon leptophyllodes, Placynthiella hyporhoda, Pyrenocarpon thelostomum, and Vezdaea acicularis, which are all recorded for the first time from New England. In addition, since the late 19th to early 20th century for New England, this survey has furnished the first modern documented records of Porocyphus coccodes, Sarcosagium campestre, and Steinia geophana, and the first such record from Maine for Coccocarpia palmicola.

No macrolichens collected for this study are species reported by Hinds and Hinds (2007) as globally rare. However, 10 taxa were found that, according to these authors, are rare in New England: seven from Pine Hill (Cladonia symphycarpa, Coccocarpia 
palmicola, Fuscopannaria praetermissa, Nephroma parile, Pannaria rubiginosa, Psorula rufonigra, and Spilonema revertens) and three from Callahan Mine (Stereocaulon condensatum, S. subcoralloides, and Leptogium imbricatum). A further three taxa from Pine Hill, Anaptychia palmulata, Cladonia boryi, and Parmotrema crinitum, are uncommon and potentially declining in New England (Hinds and Hinds 2007).

Eight additional taxa collected from Pine Hill were found by Sullivan (1996) in three or fewer study plots out of the 83 locations he surveyed: Anaptychia palmulata, Candelariella aurella, Lepraria neglecta s. lat. (syn. L. caesioalba), Pannaria rubiginosa, Placynthiella icmalea, Scoliciosporum umbrinum, Xanthoparmelia plittii, and Xanthoria elegans. Fourteen taxa collected at Callahan Mine fulfilled this criterion for local rarity: Aspicilia aff. verrucigera, Caloplaca microthallina, Candelariella aurella, Cladonia phyllophora, C. stygia, Montanelia sorediata, Physcia aipolia, P. dubia, P. subtilis, Placynthiella icmalea, Rhizocarpon grande, Scoliciosporum umbrinum, Xanthoparmelia plittii, and Xanthoria elegans.

Elemental analyses provided substrate chemistry data for the rocks (Table 1) and soils (Table 2) from which the lichens were collected. The rocks from Pine Hill were distinct from the more regionally abundant granite in their high concentrations of heavy metals, particularly $\mathrm{Cr}$ and $\mathrm{Ni}$, and low concentrations of $\mathrm{Ca}$ compared to $\mathrm{Mg}$. The granitic rocks from adjacent Settlement Quarry, which were analyzed as a comparison, contained relatively higher $\mathrm{Al}$ and $\mathrm{Si}$ and radioactive trace elements such as barium $(\mathrm{Ba})$, rubidium $(\mathrm{Rb})$, and strontium $(\mathrm{Sr})$. The mine soils from which the lichens were collected were high in $\mathrm{Cu}, \mathrm{Zn}$, and $\mathrm{Pb}$. Distinct habitats within the mine (tailings pond, waste rock piles, and 'in between') were found to differ with respect to some soil chemical features (Mansfield et al. 2014), notably higher $\mathrm{pH}, \mathrm{Ca}$, and $\mathrm{Zn}$ in the tailings pond, higher sulfur (S) in the waste rock piles, and higher $\mathrm{Pb}$ in the in between habitats.

\section{DISCUSSION}

Of the species newly reported from Pine Hill, 14 were not reported from Mont Albert by Sirois et al. (1988) and should be included in the list of species reported from serpentine from northeastern North America (Rajakaruna et al. 2009). These are Buellia lepidastra, Cladonia cryptochlorophaea, C. dimorphoclada, 
Table 1. Elemental chemistry of serpentinite and granite rock samples collected from Pine Hill and Settlement Quarry, respectively. Presence of major elements (Al-Ti) are reported as \% weight, whereas the minor elements (As- $\mathrm{Zr}$ ) are reported as ppm. Major elements and some trace elements were determined via $\mathrm{X}$-ray fluorescence analysis $(\mathrm{XRF})$. Additional trace elements (indicated by *) were determined by inductively coupled plasma-mass spectrometry (ICPMS). LOI $=\%$ loss on ignition.

\begin{tabular}{|c|c|c|}
\hline \multirow[b]{2}{*}{ Element } & \multicolumn{2}{|c|}{ Concentration of Elements } \\
\hline & Serpentinite & Granite \\
\hline \multicolumn{3}{|c|}{ Major Elements (\% weight) } \\
\hline $\mathrm{Al}$ & 6.35 & 14.17 \\
\hline $\mathrm{Ca}$ & 3.71 & 2.00 \\
\hline $\mathrm{Fe}$ & 9.25 & 2.82 \\
\hline $\mathrm{K}$ & 0.06 & 4.43 \\
\hline $\mathrm{Mg}$ & 30.25 & 0.92 \\
\hline M & 0.155 & 0.066 \\
\hline $\mathrm{Na}$ & 0.04 & 3.66 \\
\hline $\mathrm{P}$ & 0.048 & 0.171 \\
\hline $\mathrm{Si}$ & 38.08 & 70.74 \\
\hline $\mathrm{Ti}$ & 88.39 & 99.50 \\
\hline Sum & 0.453 & 0.525 \\
\hline LOI $(\%)$ & 10.43 & 0.58 \\
\hline \multicolumn{3}{|c|}{ Trace Elements (ppm) } \\
\hline $\mathrm{Ba}$ & 30 & 599 \\
\hline $\mathrm{Ce}$ & 4 & 106 \\
\hline $\mathrm{Cr}$ & 2824 & 15 \\
\hline $\mathrm{Cu}$ & 83 & 5 \\
\hline $\mathrm{Cs}^{*}$ & 0.58 & 1.94 \\
\hline Dy* & 1.58 & 6.64 \\
\hline Er* & 0.88 & 3.73 \\
\hline $\mathrm{Eu}^{*}$ & 0.41 & 1.46 \\
\hline $\mathrm{Ga}$ & 7 & 18 \\
\hline $\mathrm{Gd}^{*}$ & 1.34 & 6.65 \\
\hline $\mathrm{Hf}^{*}$ & 0.81 & 5.45 \\
\hline $\mathrm{Ho}^{*}$ & 0.32 & 1.32 \\
\hline $\mathrm{La}^{*}$ & 0.82 & 48.30 \\
\hline $\mathrm{Lu}^{*}$ & 0.13 & 0.56 \\
\hline $\mathrm{Nb}$ & 1.8 & 23.4 \\
\hline $\mathrm{Nd}$ & 3 & 44 \\
\hline $\mathrm{Ni}$ & 1527 & 10 \\
\hline $\mathrm{Pb}$ & 0 & 20 \\
\hline Pr* & 0.59 & 11.90 \\
\hline $\mathrm{Rb}$ & 2 & 152 \\
\hline $\mathrm{Sc}$ & 17 & 7 \\
\hline $\mathrm{Sm}^{*}$ & 1.05 & 7.38 \\
\hline $\mathrm{Sr}$ & 30 & 240 \\
\hline
\end{tabular}


Table 1. Continued.

\begin{tabular}{lcc}
\hline & \multicolumn{2}{c}{ Concentration of Elements } \\
\cline { 2 - 3 } Element & Serpentinite & Granite \\
\hline $\mathrm{Ta}^{*}$ & 0.02 & 2.20 \\
$\mathrm{~Tb}^{*}$ & 0.25 & 1.10 \\
$\mathrm{Th}$ & 2 & 22 \\
$\mathrm{Tm}$ & 0.12 & 0.57 \\
$\mathrm{U}^{*}$ & 0.02 & 3.60 \\
$\mathrm{~V}$ & 85 & 40 \\
$\mathrm{Y}$ & 10 & 37 \\
$\mathrm{Yb}$ & 0.78 & 3.61 \\
$\mathrm{Zn}$ & 67 & 45 \\
$\mathrm{Zr}$ & 33 & 281 \\
\hline
\end{tabular}

Table 2. Results from soil analyses at Callahan Mine shown as the mean $( \pm$ SE) for each soil feature. Locations: $\mathrm{TP}=$ tailings pond, $\mathrm{WR}=$ waste rock piles, IB = in between, including shore of Goose Pond; $\mathrm{N}=$ number of samples per location. Elemental concentrations: EC is reported as mmhos/cm and all other elemental concentrations are reported as $\mathrm{mg} / \mathrm{kg}(\mathrm{ppm})$. LOI $=$ loss on ignition $(\%)$.

\begin{tabular}{lccc}
\hline & \multicolumn{2}{c}{ Elemental Concentrations at 3 Locations } \\
\cline { 2 - 4 } Soil Feature & $\mathrm{TP}$ & $\mathrm{WR}$ & $\mathrm{IB}$ \\
$\mathrm{nyH}$ & $7.5( \pm 0.1)$ & $5.1( \pm 0.6)$ & $5.9( \pm 0.1)$ \\
\% LOI & $0.6( \pm 0.2)$ & $1.1( \pm 0.1)$ & $5.2( \pm 1.8)$ \\
$\mathrm{EC}$ & $0.8( \pm 0.3)$ & $0.7( \pm 0.1)$ & $0.7( \pm 0.2)$ \\
$\mathrm{NO}-\mathrm{N}$ & $1.8( \pm 0.4)$ & $1.4( \pm 0.3)$ & $6.2( \pm 3.1)$ \\
$\mathrm{NH} 4-\mathrm{N}$ & $3.7( \pm 0.6)$ & $2.0( \pm 0.1)$ & $8.2( \pm 5.9)$ \\
$\mathrm{Ca}$ & $16285.0( \pm 1514.9)$ & $2411.5( \pm 1291.7)$ & $2568.6( \pm 1429.0)$ \\
$\mathrm{K}$ & $11.7( \pm 0.7)$ & $10.5( \pm 1.4)$ & $105.7( \pm 41.7)$ \\
$\mathrm{Mg}$ & $100.6( \pm 10.7)$ & $66.7( \pm 9.4)$ & $102.4( \pm 32.3)$ \\
$\mathrm{Na}$ & $5.6( \pm 1.5)$ & $5.8( \pm 0.7)$ & $18.4( \pm 6.3)$ \\
$\mathrm{P}$ & $20.1( \pm 1.8)$ & $4.1( \pm 1.7)$ & $7.3( \pm 1.2)$ \\
$\mathrm{S}$ & $89.8( \pm 29.2)$ & $376.7( \pm 109.8)$ & $164.1( \pm 73.2)$ \\
$\mathrm{Al}$ & $0.4( \pm 0.0)$ & $9.5( \pm 5.8)$ & $12.4( \pm 11.6)$ \\
$\mathrm{Cd}$ & $3.0( \pm 0.9)$ & $1.3( \pm 0.5)$ & $2.7( \pm 0.7)$ \\
$\mathrm{Cr}$ & $0.0( \pm 0.0)$ & $0.0( \pm 0.0)$ & $0.1( \pm 0.0)$ \\
$\mathrm{Cu}$ & $102.6( \pm 7.2)$ & $107.7( \pm 25.8)$ & $131.6( \pm 26.4)$ \\
$\mathrm{Fe}$ & $2.5( \pm 0.9)$ & $35.8( \pm 15.6)$ & $117.2( \pm 62.9)$ \\
$\mathrm{Mn}$ & $0.8( \pm 0.2)$ & $1.8( \pm 0.7)$ & $4.2( \pm 2.0)$ \\
$\mathrm{Mo}$ & $0.5( \pm 0.0)$ & $0.3( \pm 0.1)$ & $0.4( \pm 0.1)$ \\
$\mathrm{Ni}$ & $0.5( \pm 0.2)$ & $0.5( \pm 0.1)$ & $1.5( \pm 0.6)$ \\
$\mathrm{Pb}$ & $9.2( \pm 2.7)$ & $13.2( \pm 5.7)$ & $129.1( \pm 78.1)$ \\
$\mathrm{Zn}$ & $749.8( \pm 51.9)$ & $368.5( \pm 118.6)$ & $558.5( \pm 110.2)$ \\
\hline
\end{tabular}


C. grayi, Coccocarpia palmicola, Dermatocarpon leptophyllodes, Lecidella patavina, Lepraria finkii, Physcia tenella, Placidium squamulosum, Porocyphus coccodes, Pyrenocarpon thelostomum, Rhizocarpon disporum, and Xanthoparmelia viriduloumbrina.

Of the lichen taxa newly reported from Pine Hill, Coccocarpia palmicola is a mainly tropical species that is known from isolated localities along the east coast of North America as far north as Newfoundland (CNALH 2013). Our collection is only the second record of C. palmicola in New England since the late 19th to early 20th century, and only the second ever in Maine (Hinds and Hinds 2007). This species has declined in its New England distribution over the past century (Hinds and Hinds 2007), possibly due to the susceptibility of cyanolichens to increased air pollution (Richardson and Cameron 2004). Nephroma parile and Pannaria rubiginosa, two regionally rare cyanolichens (Hinds and Hinds 2007) from Pine Hill, may be in decline for the same reason.

Dermatocarpon leptophyllodes is possibly new to eastern North America because it was not included in Hinds and Hinds (2007) and all the records in CNALH (2013) are from western states, whereas Pyrenocarpon theostomum has previously been reliably reported from North America only from Illinois (M. Schultz, Biozentrum Klein Flottbek und Botanischer Garten der Universität Hamburg, Hamburg, Germany, pers. comm.), not Michigan as reported by Dillman et al. (2012). Both were found at Pine Hill in a calcareous seep along with Porocyphus coccodes, which is apparently the first recent record for New England since it was collected by H. Willey in Massachusetts in the 19th century (CNALH 2013). Similarly, Coccocarpia palmicola, which has been found on calcareous substrates in Massachusetts (Hinds and Hinds 2007), and other species known to favor substrates with a high $\mathrm{pH}$, was also found at Pine Hill. This is presumably the result of preferential leaching of basic cations from the serpentine substrate, a similar effect to that reported by Miller et al. (2005) from granitic rocks on Katahdin. Coccocarpia palmicola, however, is usually a corticolous species and its occurrence in a basic seep on serpentine is most probably a result of the additional nutrients provided by this habitat that allow it to occur outside its normal range. Two other Pine Hill lichens (Cladonia symphycarpa and Fuscopannaria praetermissa), considered as rare in New England (Hinds and Hinds 2007), are also calcicoles. 
Rarity is not a trait exclusive to calcicoles at Pine Hill. Psorula rufonigra and Spilonema revertens are two intimately linked lichen taxa, with $P$. rufonigra occurring only on the thallus of $S$. revertens. They usually occur on acidic rocks but have previously been documented in northern New England only on serpentine in Vermont (Hinds and Hinds 2007), and were again reported from serpentine at Pine Hill. Other uncommon calcifuge species include Anaptychia palmulata and Parmotrema crinitum, which are described in Hinds and Hinds (2007) as uncommon, and Cladonia boryi, which has experienced a range contraction in New England over the past century; it is common on the coast of Maine, but uncommon elsewhere (Hinds and Hinds 2007).

Of the species newly reported from Callahan Mine, Placynthiella hyporhoda, Sarcosagium campestre, Steinia geophana, and Vezdaea acicularis are inconspicuous terricolous species that are almost certainly under recorded. However, only Sarcosagium campestre and Steinia geophana have previously been documented from New England: $S$. campestre from a 1938 record from Vermont and $S$. geophana from a 19th century record from Massachusetts (CNALH 2013). The two, newly reported Stereocaulon species $(S$. condensatum and $S$. subcoralloides) are also both terricolous species, and although both have previously been reported from Maine, both are rare with only scattered occurrences (Hinds and Hinds 2007). Although not restricted to soils with a high mineral content, all these species are often found associated with disused heavy metal mines (Plantlife 2012; Purvis and Halls 1996) and the occurrence of these rare terricolous species at Callahan Mine is probably an indirect effect of the high metal content of the soil that suppresses vascular plant growth and provides a suitable substrate for their development.

Two collections from the waste rock pile at Callahan Mine were clearly referable to the genus Amandinea (pigmented 1-septate ascospores, long curved conidia) but could not confidently be identified to species. The immature ascospores had the thickened septum typical of $A$. pelidna but the thallus was not as well developed as is usual for this species and the ascospores were also smaller than is typical for both $A$. pelidna and A. punctata. They are treated here, along with previous collections, as $A$. punctata aggr.

Also collected from Callahan Mine was an Aspicilia sp. similar to A. verrucigera but with smaller ascospores [13-15(-16) $\times 8-10 \mu \mathrm{m}]$ 
and conidia [(11-)12-13(-15) $\mu \mathrm{m}$ long], both with a limited range, that is probably con-specific with 'A. verrucigeroides' (I. Brodo, Canadian Museum of Nature, pers. comm.). Molecular analysis will be undertaken to determine the systematic position of this collection. As A. verrucigera has previously been reported from this site we have not included this as a new taxon, but changed the listing to $A$. aff. verrucigera in Appendix.

Leptogium imbricatum is a rare calcicolous species that was collected at Callahan Mine near Goose Pond. Although we do not have a $\mathrm{pH}$ value for the exact location of this collection, a $\mathrm{pH}$ of 5.9 was reported for the 'in-between' soils (Table 2), which included soils collected along Goose Pond. Rajakaruna et al. (2011) attribute the presence of this and other calcicolous species at Callahan Mine to mortar and concrete debris left by the mining operations. Also collected from near Goose Pond was Physica subtilis, which is a species of non-calcareous rocks, often in sites with sunlight exposure (Brodo et al. 2001). Maine is at the northernmost edge of its range and it was represented in Sullivan (1996) by a single specimen found on an acidic cliff face. The neutral to slightly basic $\mathrm{pH}$ at the tailings pond, as compared to the low $\mathrm{pH}$ values recorded for the waste rock piles and 'in-between' area, does not exert a discernible effect on the distribution of lichens at Callahan Mine. However, the four taxa reported from only the tailings pond, Peltigera canina, P. rufescens, Sarcosagium campestre, and Steinia geophana, all occur primarily on bare, damp ground and are typical of recently disturbed soils, although only $P$. rufescens is reported to occur mainly on basic substrata. Although it is difficult to attribute any one edaphic factor to the presence of a lichen species, it is likely that the fine-textured (silt-clay), metal-enriched, and water-logged soils at the tailings pond have created a unique habitat for some soil-crust colonizing lichens.

Five of the species newly reported from Callahan Mine (all from damp soil)-Placynthiella hyperhoda, Sarcosagium campestre, Steinera geophana, Stereocaulon condensatum, and Vezdaea acicularus - are considered indicators of an important site for metal-tolerant lichens (Plantlife 2012). With the addition of Acarospora sinopica, Stereocaulon dactylophyllum, and S. pileatum, which were already reported from the site, there are now eight taxa considered indicators. Although the Plantlife indicator list was intended for metalliferous sites in Wales, it is still relevant to eastern North America and, in fact, a further species, Stereocaulon 
subcoralloides, should probably be added to the list for eastern North America. The presence of three indicator species is considered to be sufficient to designate a site as important for metal-tolerant lichens (Plantlife (2012), so the occurrence of eight indicator species at Callahan Mine is indicative of a very important site.

Although the importance of rock mineralogy, including elemental geochemistry, in determining the composition of saxicolous lichen communities has long been recognized (Purvis and Halls 1996), attempts to analyze the distribution of saxicolous lichens according to their lithochemistry are not very common (Brodo 1973; Werner 1956). Further, studies that directly associate mineralogy or elemental chemistry of host rocks to the presence of lichen species or the assemblage of lichen communities are extremely rare (Boyle et al. 1987; Rajakaruna et al. 2012). Although complex interactions between lichens and rocks and lichens and elements are often noted (Hauck et al. 2007; Purvis 1996; Richardson 1995; Shimizu 2004; Wilson 1995), the exact nature of this substratum-level influence on lichens (i.e., whether chemical and/or textural) is unclear (Rajakaruna et al. 2012). Our sampling strategy does not allow us to directly associate the presence of any lichen species that we collected with the concentration of a particular element or combination of elements. However, our analyses of substrate chemistry of the rocks and soils from which these lichens were collected have improved the characterization of the range of elemental tolerances for the lichens found at Pine Hill and Callahan Mine.

Our study has highlighted the importance of metal rich rocks and soils in harboring rare and unusual lichen species and assemblages. An informal survey by the authors of the granitic Settlement Quarry in the vicinity of Pine Hill suggests that there are major differences between the two sites with regard to the most prevalent saxicolous species (Medeiros et al., unpubl. data). However, it is unclear whether these differences result from the chemical differences we have reported (Table 1) or from surface textural differences observed between granitic and serpentinite rocks. Surveys of geographically and climatically similar areas with different geologies could help answer the question of whether the number of regionally rare or uncommon lichen species at Pine Hill and Callahan Mine can be attributed to chemical or physical features of the substrate, or whether other factors not directly 
related to geology are the dominant forces at work. Such surveys could also reaffirm the importance of conserving diverse habitats to protect the diversity of lichens. Additional work to document lichens on serpentine outcrops and mine sites elsewhere that are exposed to a wide range of climatic and edaphic variation will help document the lichen biota of understudied habitats and contribute to our understanding of the effects of heavy metals and harsh environments on lichen diversity.

ACKNOWLEDGMENTS. The authors thank the Island Heritage Trust of Deer Isle for permission to collect at Pine Hill and for continued support of our research activities at the Pine Hill Preserve and Settlement Quarry; Naji Akladiss (U.S. Environmental Protection Agency) and Sally N. Mills (Hale \& Hamlin, LLC) for providing access to Callahan Mine; Richard Harris (New York Botanical Garden) for collections made at Pine Hill; Irwin M. Brodo (Canadian Museum of Nature, Ottawa) and James C. Lendemer (New York Botanical Garden) for help with a difficult Lepraria specimen; Björn Owe-Larsson (Herbarium, Botany Section, Museum of Evolution, Uppsala, Sweden) and Matthias Schultz (Biozentrum Klein Flottbek und Botanischer Garten der Universität Hamburg, Hamburg, Germany) for identifying specimens of Aspicilia and Lichinaceae (Porocyphus and Pyrenocarpon), respectively; and Irwin M. Brodo, and two anonymous reviewers for their careful reviews that greatly improved the paper.

\section{LITERATURE CITED}

ANACKer, B. L. 2011. Phylogenetic patterns of endemism and diversity, pp. 49-79. In: S. P. Harrison and N. Rajakaruna, eds., Serpentine: The Evolution and Ecology of a Model System. University of California Press, Berkeley, CA.

Antonovics, J. 2006. Evolution in closely adjacent plant populations. X. Longterm persistence of prereproductive isolation at a mine boundary. Heredity 97: 33-37.

BAČKOR, M. AND S. LopPI. 2009. Interactions of lichens with heavy metals. Biol. Pl. 53: 214-222.

BAtEs, J. W. 1978. The influence of metal availability on the bryophyte and macrolichen vegetation of four rock types on Skye and Rhum. J. Ecol. 66: 457-482.

Boyle, A. P., P. M. McCarthy, and D. Stewart. 1987. Geochemical control of saxicolous lichen communities on the Creggaun Gabbro, Letterfrack, Co. Galway, western Ireland. Lichenologist 19: 307-317. 
Brady, K. U., A. R. Kruckeberg, and H. D. Bradshaw Jr. 2005. Evolutionary ecology of plant adaptation to serpentine soils. Annual Rev. Ecol. Evol. Syst. 36: 243-266.

Briscoe, L. R. E., T. B. Harris, E. Dannenberg, W. Broussard, F. C. Olday, AND N. RAJAKARUNA. 2009. Bryophytes of adjacent serpentine and granite outcrops on the Deer Isles, Maine, USA. Rhodora 111: 1-20.

Brodo, I. M. 1973. Substrate ecology, pp. 410-441. In: V. Ahmadjian and M. E. Hale, eds., The Lichens. Academic Press, New York, NY.

S. D. Sharnoff, and S. Sharnoff. 2001. Lichens of North America. Yale University Press, New Haven, CT.

CNALH. 2013. Consortium of North American Lichen Herbaria. CNALH Administration at Arizona State University, Tempe, AZ, Website (http:// lichenportal.org/portal/index.php). Accessed 5 Dec 2013.

Dillman, K. L., T. Ahti, And C. R. Björk, et al. (2012). New records, range extensions, and nomenclatural innovations for lichens and lichenicolous fungi from Alaska, U.S.A. Herzogia 25: 177-210.

Environmental Protection Agency. 2013. Waste site cleanup and reuse in New England. U.S. EPA, Region 1, Boston, MA. Website (http://www. epa.gov/region1/superfund/sites/callahan). Accessed 8 Dec 2013.

Esslinger, T. L. 2012. A cumulative checklist for the lichen-forming, lichenicolous, and allied fungi of the continental United States and Canada. North Dakota State University, Fargo, ND, Website (http:// www.ndsu.nodak.edu/instruct/esslinge/chcklst/chcklst7.htm). Accessed 26 Oct 2013.

Favero-Longo, S. E., D. Isocronso, and R. Piervittori. 2004. Lichens and ultramafic rocks: A review. Lichenologist 36: 391-404.

Gowan, S. P. And I. M. Brodo. 1988. The lichens of Fundy National Park, New Brunswick, Canada. Bryologist 91: 255-325.

Harris, T. B., F. C. Olday, and N. Rajakaruna. 2007. Lichens of Pine Hill, a peridotite outcrop in eastern North America. Rhodora 109: 430-447.

Harrison S. P. and N. Rajakaruna, eds. 2011. Serpentine: The Evolution and Ecology of a Model System. University of California Press, Berkeley, CA.

Hauck, M., S. Huneck, J. A. Elix, and A. Paul. 2007. Does secondary chemistry enable lichens to grow on iron-rich substrates? Flora 202: 471-478.

Hinds, J. W. AND P. L. Hinds. 2007. The Macrolichens of New England. New York Botanical Garden Press, New York, NY.

Hooke, R. LeB. 2003. A Geologic History of Deer Isle, Maine: A Thumb Nail Sketch. Published by the author, Orono, ME.

Index Fungorum Partnership. 2014. Index Fugorum. A community resource. CABI, CBS, and Landcare Research, custodians. CABI, Wallingford, Oxfordshire, U.K.; CBS KNAW Fungal Biodiversity Centre, Utrecht, The Netherlands; and Manaaki Whenua - Landcare Research, Lincoln, New Zealand. Website (http://www.indexfungorum.org). Accessed Jun 2014.

Kay, K. M., K. L. Ward, L. R. Watt, and D. W. Schemske. 2011. Plant speciation, pp. 97-137. In: S. P. Harrison and N. Rajakaruna, eds., Serpentine: Evolution and Ecology in a Model System. University of California Press, Berkeley, CA. 
Kruckeberg, A. R. 1986. An essay: The stimulus of unusual geologies for plant speciation. Syst. Bot. 11: 455-463.

- 2002. Geology and Plant Life: The Effects of Landforms and Rock Type on Plants. University of Washington Press, Seattle, WA.

Lambinon, J., A. Maquinay, And J. L. Ramaut. 1964. La teneur en zinc de quelques lichens des terrains calaminaires Belges. Bull. Jard. Bot. de l'État. (Bruxelles) 34: 273-282.

Mansfield, M., N. Pope, G. Mittlehauser, and N. Rajakaruna. 2014. Diversity and soil-tissue elemental relations of vascular plants of Callahan Mine, Brooksville, Maine, USA. Rhodora 116: xxx-yyy.

Maquinay, A., I. M. Lamb, J. Lambinon, and J. L. Ramaut. 1961. Dosage du zinc chez un lichen calaminaire Belge: Stereocaulon nanodes Tuck. f. tyroliense (Nyl.) M. Lamb. Physiol. Pl. (Copenhagen) 14: 284-289.

Miller, N. G., A. M. Fryday, And J. W. Hinds. 2005. Bryophytes and lichens of a calcium-rich spring seep isolated on the granitic terrain of Mt. Katahdin, Maine, U.S.A. Rhodora 107: 339-358.

O'Dell, R. E. AND N. RAJAKARUNA. 2011. Intraspecific variation, adaptation, and evolution, pp. 97-137. In: S. P. Harrison and N. Rajakaruna, eds., Serpentine: Evolution and Ecology in a Model System. University of California Press, Berkeley, CA.

Orange, A., P. W. James, And F. J. White. 2001. Microchemical Methods for the Identification of Lichens. British Lichen Society, London, UK.

Plantlife. 2012. Heavy-metal Lichens in Wales. A Management Guide. Plantlife Cymru, Bangor, Gwynedd, Wales, UK.

Pope, N., T. B. Harris, and N. RaJakaruna. 2010. Vascular plants of adjacent serpentine and granite outcrops on the Deer Isles, Maine, U.S.A. Rhodora 112: $105-141$.

Purvis, O. W. 1993. The botanical interest of mine spoil heaps: The lichen story. J. Russell Soc. 5: 45-48.

. 1996. Interactions of lichens with metals. Sci. Progr. 79: 283-309.

AND C. Halls. 1996. A review of lichens in metal-enriched environments. Lichenologist 28: 571-601.

Rajakaruna, N. and R. S. Boyd. 2008. The edaphic factor, pp. 1201-1207. In:

S. E. Jorgensen and B. Fath, eds., The Encyclopedia of Ecology, Vol. 2. Elsevier, Oxford, U.K.

, T. B. Harris, and E. B. Alexander. 2009. Serpentine geoecology of eastern North America: A review. Rhodora 111: 21-108.

- - , S. R. Clayden, A. C. Dibble, and F. C. Olday. 2011. Lichens of the Callahan Mine, a copper- and zinc-enriched superfund site in Brooksville, Maine, U.S.A. Rhodora 113: 1-31.

, K. Knudsen, A. M. Fryday, R. E. O'Dell, N. Pope, F. C. Olday, and S. Woolhouse. 2012. Investigation of the importance of rock chemistry for saxicolous lichen communities of the New Idria serpentinite mass, San Benito County, California, USA. Lichenologist 44: 695-714.

ReED, C. F. 1986. Flora of the Serpentinite Formations in Eastern North America, with Descriptions of the Geomorphology and Mineralogy at the Formations. Contrib. 30. Reed Herbarium, Baltimore, MD.

Richardson, D. H. S. 1995. Metal uptake in lichens. Symbiosis 18: 119-127. 
And R. P. CAmeron. 2004. Cyanolichens: Their response to pollution and possible management strategies for their conservation in northeastern North America. N. E. Naturalist 11: 1-22.

Roberts, B. A. And J. Proctor, eds. 1992. The Ecology of Areas with Serpentinized Rocks: A World View. Kluwer Academic Publishers, Dordrecht, The Netherlands.

Safford, H. D., J. H. Viers, and S. P. Harrison. 2005. Serpentine endemism in the California flora: A database of serpentine affinity. Madroño 52: 222-257.

Shimizu, A. 2004. Community structure of lichens in the volcanic highlands of Mt. Tokachi, Hokkaido, Japan. Bryologist 107: 141-151.

Sirois, L., F. Lutzoni, AND M. M. GrandTNER. 1988. Les lichens sur serpentine et amphibolite du plateau du Mont Albert, Gaspésie, Québec. Canad. J. Bot. 66: 851-862.

Sullivan, T. J. 1996. The lichens of Acadia National Park, Maine. Ph.D. dissertation, University of Minnesota, Minneapolis, MN.

Werner, R. G. 1956. Etudes ecologiques sur les lichens des terrains schisteux maritimes. Bull. Soc. Sci. Nancy, n. ser. 15: 137-152.

WiLson, M. J. 1995. Interactions between lichens and rocks: A review. Cryptog. Bot. 5: 299-305. 
2014] Medeiros et al.- - Lichens of Contaminated Sites

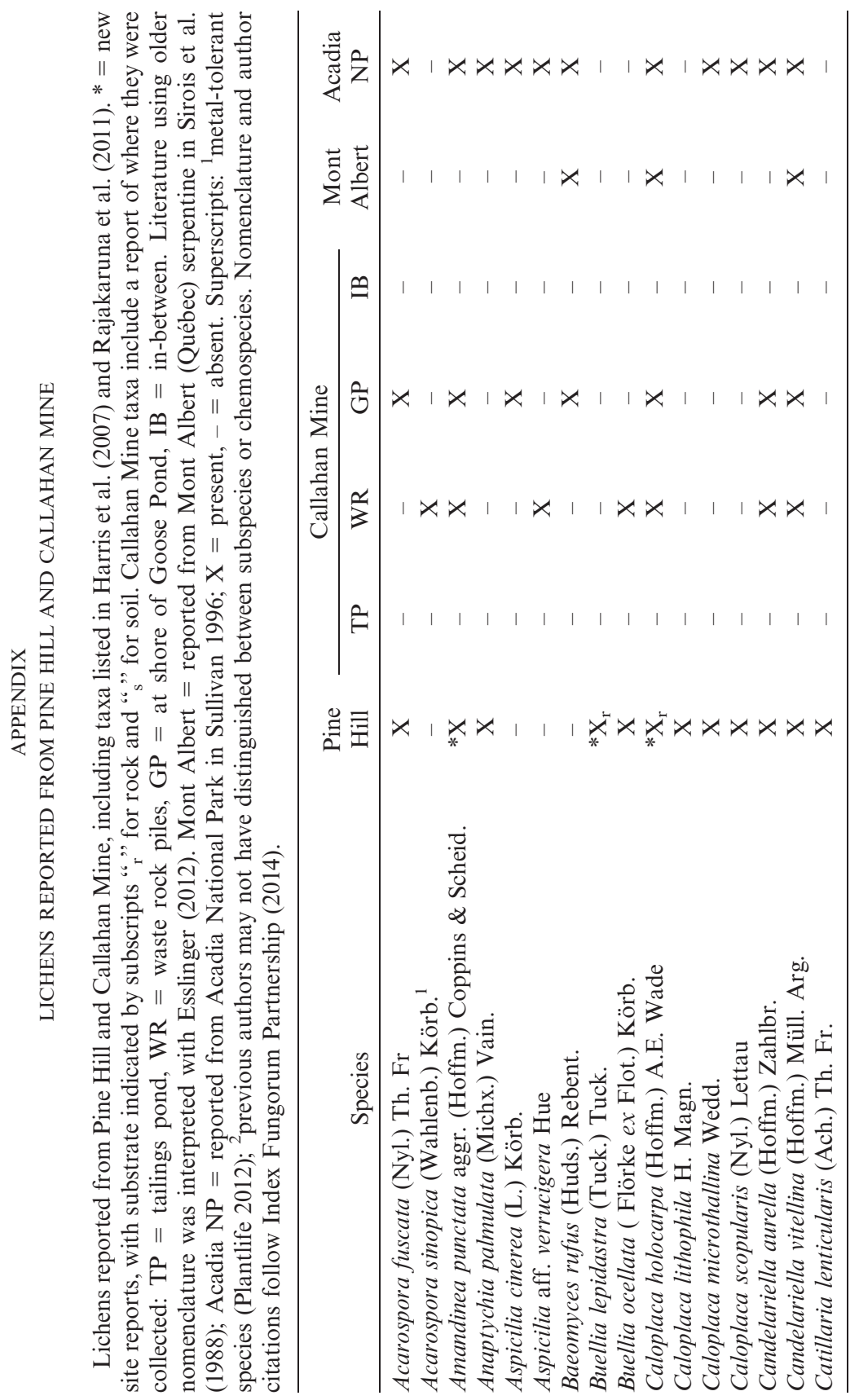


0

Rhodora

[Vol. 116

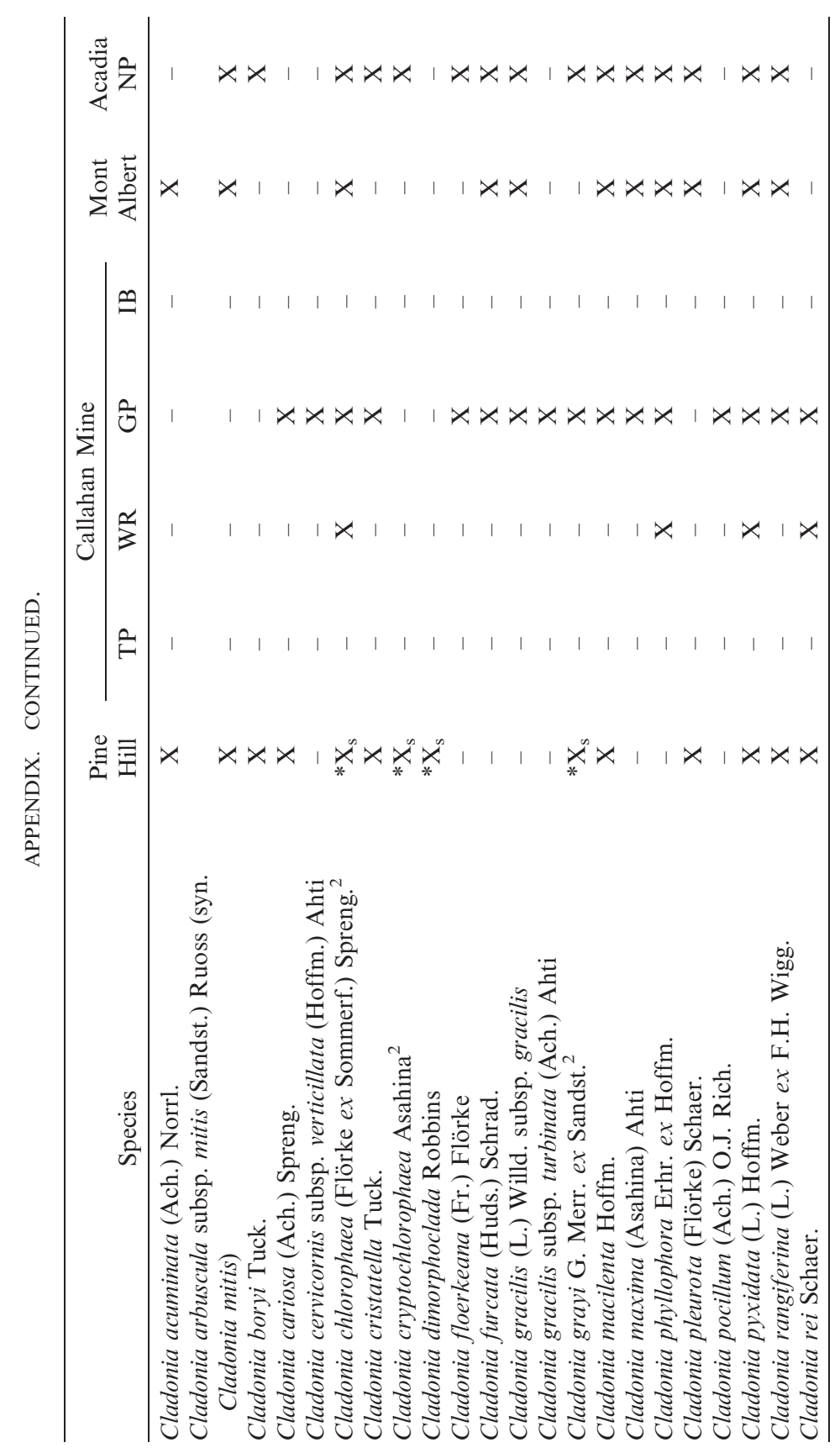




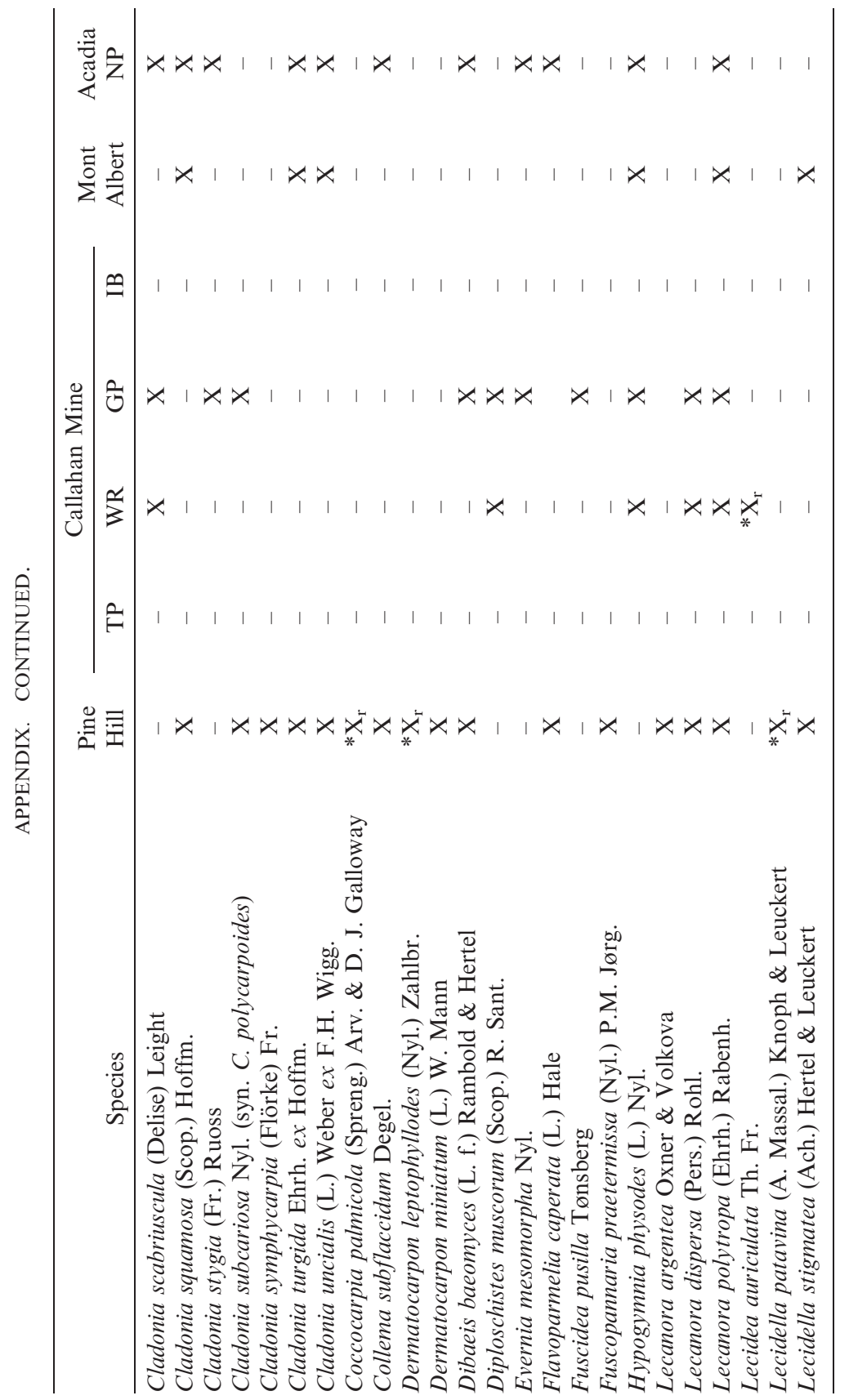


0

Rhodora

[Vol. 116

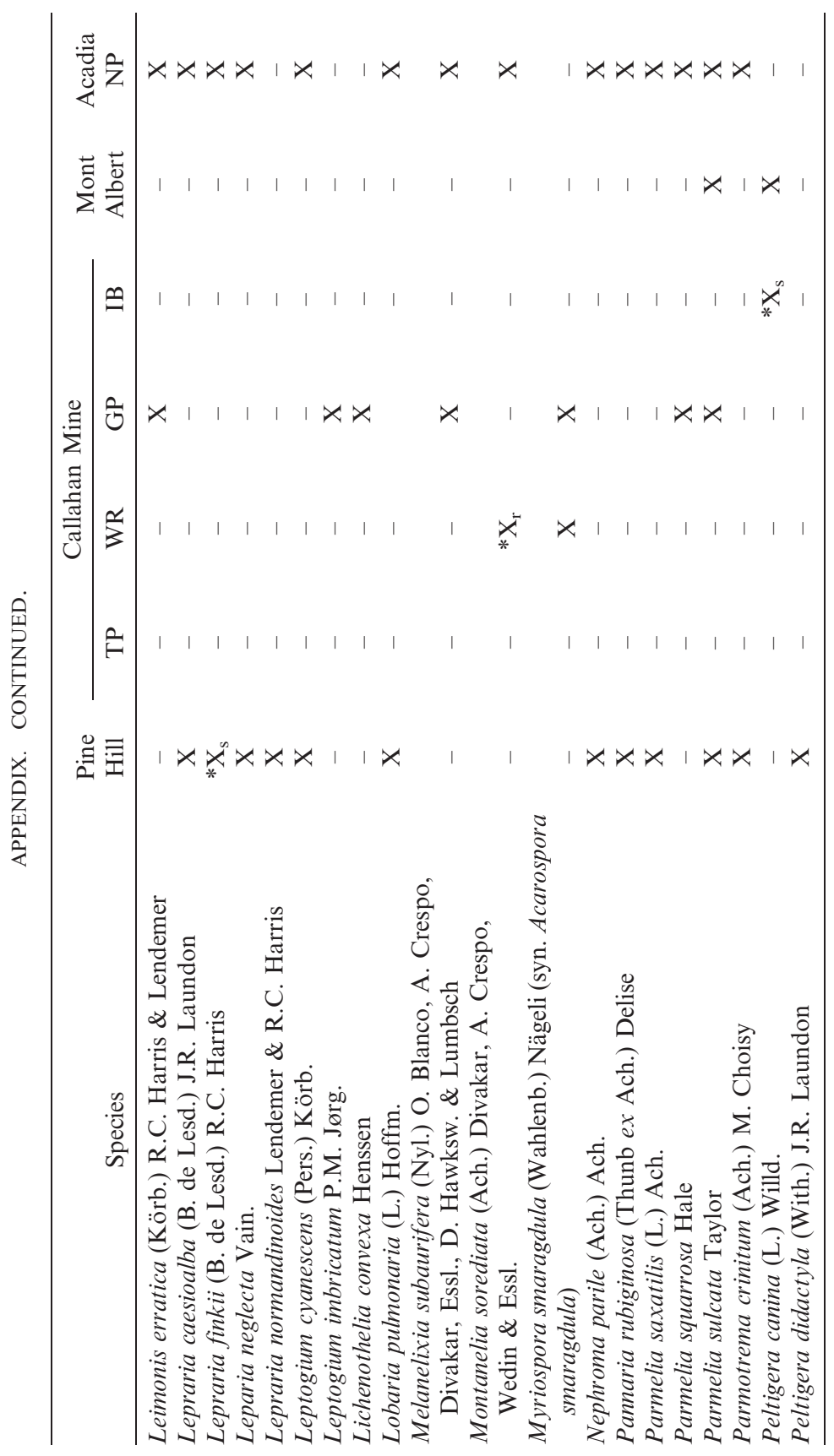




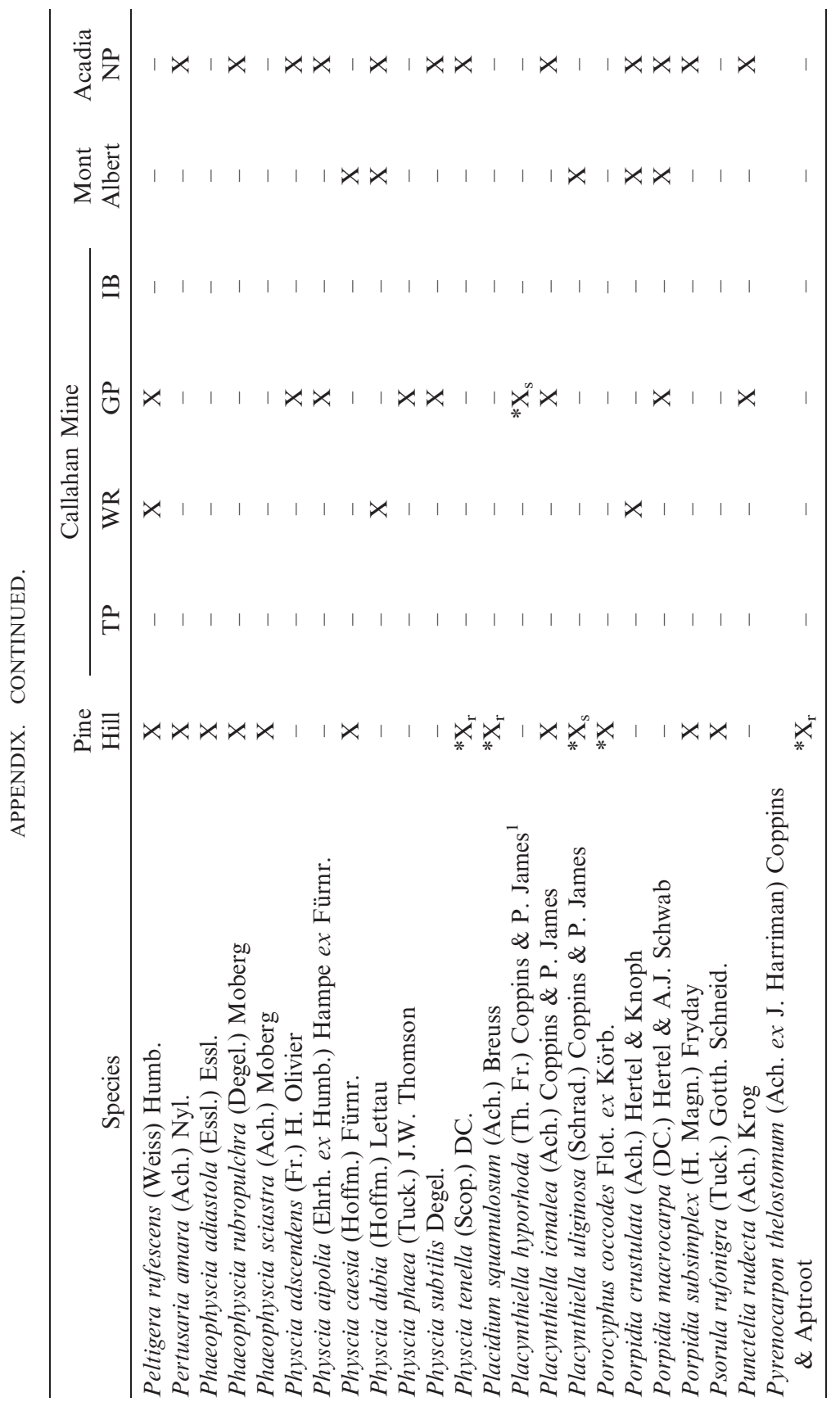


0

Rhodora

[Vol. 116

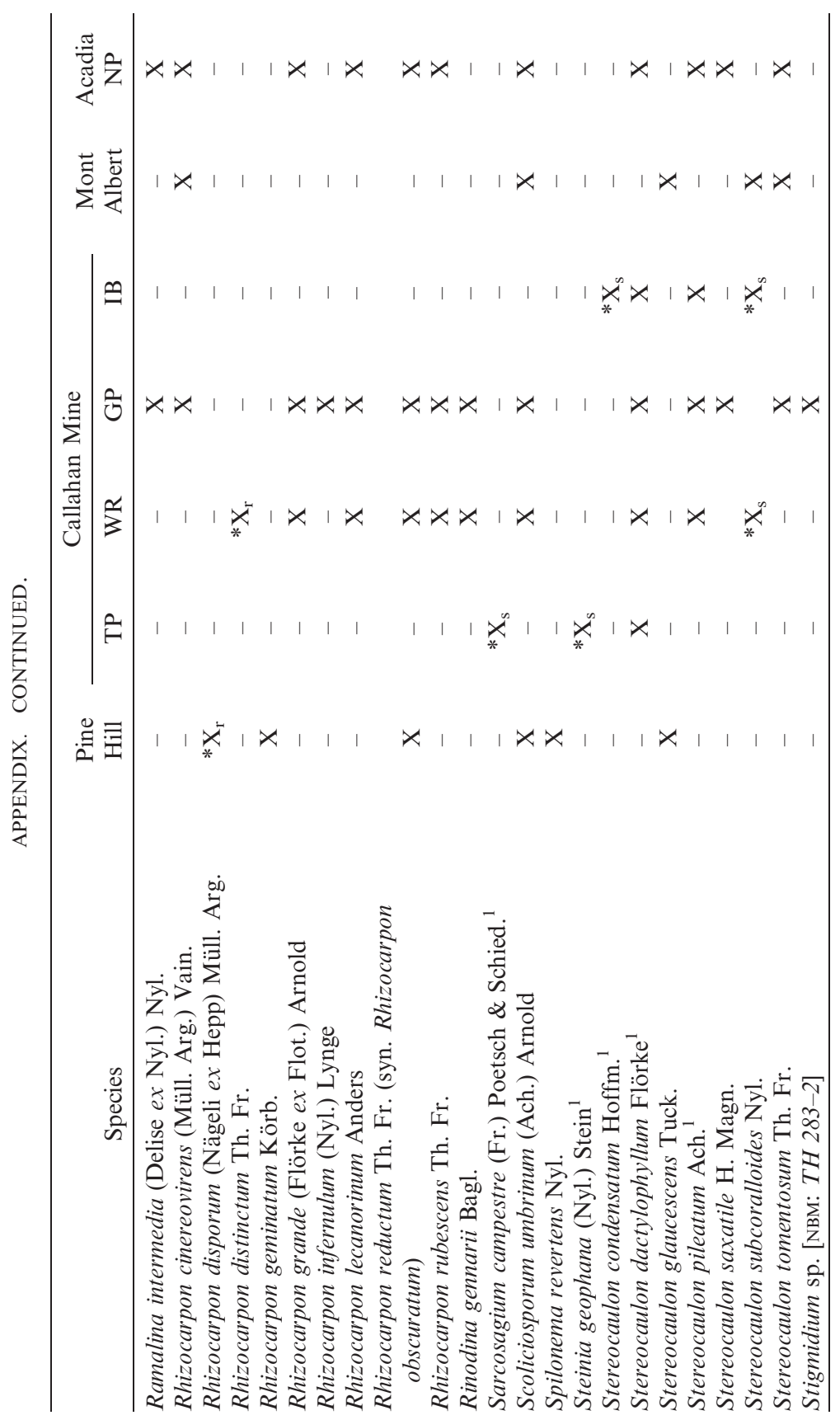


2014] Medeiros et al._-Lichens of Contaminated Sites

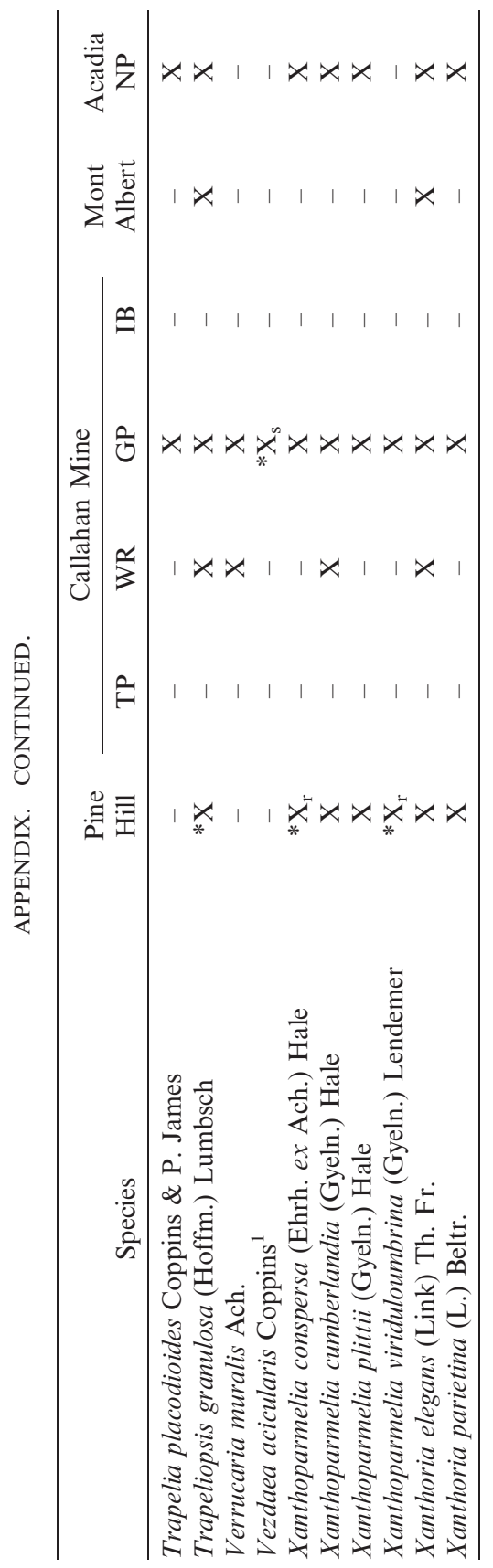

